\title{
Factors Influencing the Occurrence of Foliar Pathogens in Commercial Watermelon Fields in South Carolina Based on Stratified Cluster Sampling
}

\author{
Gabriel Rennberger, ${ }^{1, \dagger}$ Patrick Gerard, ${ }^{2}$ and Anthony P. Keinath ${ }^{1}$ \\ ${ }^{1}$ Clemson University, Coastal Research and Education Center, Charleston, SC 29414; and ${ }^{2}$ Clemson University, Department of \\ Mathematical Sciences, Clemson, SC 29634
}

\begin{abstract}
The influence of environmental and management factors on the occurrence of foliar pathogens of watermelon was analyzed using surveysampling data collected from commercial farms in South Carolina in spring 2015 and spring and fall 2016. A stratified two-stage cluster sampling design was used to sample symptomatic watermelon leaves from 56 fields of 27 growers in seven counties representing the main watermelon-producing areas in the state. In the sampling design, counties corresponded to strata, growers to first-stage clusters, and fields to second-stage clusters. Pathogens were identified on 100 leaves collected per field based on reproductive structures that formed on the leaves. Information about previous crops, fruit type, field size, transplanting date, first harvest date, and fungicides applied within 7 days and within 7 to 14 days prior to sampling was obtained from growers. Field alignment was determined with a compass. Survey-specific logistic regression procedures were used to analyze the effect of these factors on the probabilities of pathogen occurrence. Five fungal pathogens, Stagonosporopsis spp., Podosphaera xanthii, Cercospora citrullina, Colletotrichum orbiculare, and Myrothecium sensu lato

(s.1.), and the oomycete Pseudoperonospora cubensis were included in the analyses. Among the factors we analyzed, there was a consistent increased probability of occurrence of Stagonosporopsis spp. in fields with a previous cucurbit crop, increasing probabilities of pathogen occurrence with increasing plant age, a lower probability of occurrence of some pathogens on triploid cultivars compared with diploid cultivars, and a decrease in probability of pathogen occurrence in fields aligned toward southwest or west. Application of fungicides significantly reduced the probability of observing C. citrullina, P. cubensis, and Stagonosporopsis spp. in 2015 and P. xanthii in spring 2016. This study emphasizes the importance of crop rotation and fungicide applications to manage foliar diseases of watermelon, particularly gummy stem blight, powdery mildew, and downy mildew. Crop age, cultivar type, and field alignment also were found to significantly influence the probability of pathogen occurrence. To the best of our knowledge, this is the first study examining the influence of various factors on foliar pathogens of watermelon with data collected from commercial fields.
\end{abstract}

Watermelon production, which occurred on 2,875 ha and was valued at $\$ 33.7$ million in 2017 , is an important part of agriculture in South Carolina (USDA, NASS 2018). Apart from Fusarium wilt caused by Fusarium oxysporum $\mathrm{f}$. sp. niveum, the main challenges in watermelon production in the United States are foliar diseases (Kousik et al. 2016). In a recent survey of foliar diseases of watermelon on commercial farms in South Carolina, we identified six fungal pathogens, one oomycete, and three viral pathogens on leaves collected from 60 fields over the course of four seasons. In descending order of prevalence across seasons, the diseases observed were gummy stem blight, powdery mildew, Cercospora leaf spot, Myrothecium leaf spot, anthracnose, and downy mildew (Rennberger et al. 2018).

Gummy stem blight is caused by three distinct, closely related Stagonosporopsis species, S. citrulli, S. caricae, and S. cucurbitacearum (syn. Didymella bryoniae), that are morphologically indistinguishable. $S$. citrulli has the widest distribution and is the most common species in the southeastern United States (Brewer et al. 2015; Li and Brewer 2016; Rennberger et al. 2018; Stewart et al. 2015). S. caricae also has been found in the southeastern United States at low frequencies

${ }^{\dagger}$ Corresponding author: G. Rennberger; E-mail: grennbe@clemson.edu

Funding: This research is based on work that is supported in part by the National Institute of Food and Agriculture, U.S. Department of Agriculture, under project number SC-1700536, and the Agricultural Marketing Service, U.S. Department of Agriculture, under prime grant agreement \#15SCBGP-SC-0013.

Technical Contribution number 6676, Clemson University Experiment Station.

Accepted for publication 4 September 2018.

() 2019 The American Phytopathological Society on watermelon. S. cucurbitacearum has been reported primarily from temperate regions. All aboveground plant parts can be affected by the disease, and 37 species of cucurbits are known to be susceptible (Rennberger and Keinath 2018). The pathogen overwinters on infected crop debris and can also be seedborne (Keinath 2017b).

Powdery mildew is a major constraint to global cucurbit production. $P$. xanthii is the predominant powdery mildew pathogen in the southeastern United States (Keinath 2015c; McGrath 2017; Rennberger et al. 2018). Cucurbit powdery mildew fungi are obligate biotrophs that are mainly dispersed via airborne conidia. The pathogen can overwinter on infected cucurbit plants and alternative hosts like Verbena spp. (Cho et al. 2014; McGrath 2017). Another minor means of overwintering is chasmothecia, which are formed under cool conditions at the end of a growing season (McGrath 2017).

Cercospora leaf spot is caused by Cercospora citrullina (Everts 2017). Based on molecular phylogeny, this taxon may be a species complex (Groenewald et al. 2013). The disease affects most cucurbits and is commonly observed on watermelon (Everts et al. 2016). The pathogen overseasons on crop debris and weedy members of the cucurbit family. The airborne spores can be transported long distances with wind driven rain and require free water for infection (Everts 2017).

Downy mildew of cucurbits is caused by the oomycete Pseudoperonospora cubensis. $P$. cubensis is an obligate biotroph and requires host plants to survive between seasons. In North America, P. cubensis is not known to overwinter in the field in regions above the $30^{\circ}$ latitude where annual frosts kill the cucurbit hosts (Ojiambo et al. 2015). Recently however, it was shown that isolates of both mating types of the pathogen from the southern United States can produce oospores on cucumber and cantaloupe. Oospores might therefore also enable P. cubensis to overwinter in the United States (Thomas et al. 2017).

The causal agent of cucurbit anthracnose is the fungus Colletotrichum orbiculare, which has three races. Race 2 is pathogenic to all watermelon cultivars, while open-pollinated and heirloom cultivars are also susceptible to races 1 and 2B (Keinath 2015a; Wasilwa 
et al. 1993). Colonized plant debris and infected volunteer plants serve as overwintering sites for $C$. orbiculare, which can also be seedborne (Keinath 2017a).

Myrothecium leaf spot is a disease most likely caused by several species in the species complex Myrothecium sensu lato (s.1.) (Bruton and Fish 2017; Lombard et al. 2016). The disease can affect cucurbit foliage, crowns, stems, and fruits. On fruits it is referred to as crater rot. The pathogen is a common soil inhabitant, but there is no specific information about its mode of overwintering (Bruton and Fish 2017).

Fungicide applications are indispensable in the management of foliar diseases of cucurbits such as anthracnose, downy mildew, gummy stem blight, and powdery mildew (Keinath 2001, 2015b, c, 2016, 2018; McGrath 2001; Ojiambo et al. 2010). However, fungicides did not appear to influence pathogen occurrence in a survey of foliar pathogens on cucumbers in North Carolina, but the effects were not analyzed statistically (Peterson and Campbell 2002). To the best of our knowledge, the effect of fungicides on the occurrence of foliar pathogens on cucurbits has never been analyzed for data collected from commercial farms. Such data would serve to validate fungicide recommendations and applications better than data generated in small research plots.

The effect of crop rotation on the occurrence and severity of plant diseases has been documented for many different pathosystems (Gugino et al. 2007; Hao et al. 2003; Shtienberg and Fry 1990). Only a few studies have examined the influence of crop rotation on cucurbit diseases, such as gummy stem blight. In two different studies, gummy stem blight was less severe on watermelon or cucumber in rotated than in nonrotated treatments (Keinath 1996; Sitterly 1969).

The differential susceptibility of various cucurbit species and cultivars to foliar diseases, especially gummy stem blight, has been demonstrated previously (Keinath 2014). Watermelon is among the cucurbits most susceptible to gummy stem blight. However, triploid watermelon cultivars were found to be less susceptible to anthracnose, gummy stem blight, and powdery mildew than diploid cultivars in field experiments in South Carolina (Keinath 2014; Keinath and Hassel 1999, 2000). However, the number of watermelon cultivars with resistance to foliar diseases is limited to several commercially acceptable cultivars with tolerance or resistance to anthracnose race
1 and one cultivar with resistance to powdery mildew (Kemble et al. 2018).

Long-distance transport of plant-pathogenic fungi and oomycetes, defined as transport $\geq 100 \mathrm{~m}$, is dependent on wind speed and direction among other factors (Neufeld et al. 2018; Prussin et al. 2015). Through an influence on wind speed and direction, the alignment of a field can affect air circulation and leaf wetness levels in the field. Therefore, field alignment has been recommended as a cultural management technique to reduce severity of foliar diseases (Everts and Himmelstein 2010). A significant effect of field alignment on ray blight of pyrethrum has been shown previously, as severity was influenced by leaf wetness duration and wind direction (Pethybridge and Hay 2001).

The objectives of this study were to determine the influence of environmental and management factors on the occurrence of foliar pathogens in commercial watermelon fields in South Carolina. The environmental factors included in the study were county, plant age, and sampling date. The management factors included were crop rotation, ploidy level, field size, field alignment, and fungicide applications within 2 weeks of sampling leaves. Estimates of the influence of these factors were obtained by using a complex sampling design as described in Rennberger et al. (2018) followed by logistic regression analysis for survey data.

\section{Materials and Methods}

Sampling design. A stratified two-stage cluster sampling design was used to sample symptomatic watermelon leaves from commercial fields in 2015 and 2016. In 2016, both spring and fall crops were sampled. Preselected counties represented the strata in the design. Counties with the highest recorded watermelon acreage were chosen (USDA, NASS 2014). Six counties were sampled in 2015, seven in the spring of 2016, and six in the fall of 2016 (Table 1).

Growers, who were selected randomly from a compiled list obtained from Clemson Cooperative Extension agents, represented the first level of clustering within each county. Sixteen, 17, and 7 different growers were included in spring 2015, spring 2016, and fall 2016, respectively. In total, fields from 27 different growers were sampled, of which two were sampled in all three seasons; eight were

Table 1. Watermelon fields sampled in three seasons in 2015 and 2016 in South Carolina

\begin{tabular}{|c|c|c|c|c|c|c|c|}
\hline Season & County & $\begin{array}{l}\text { Acreagew } \\
\text { (ha) }\end{array}$ & $\begin{array}{c}\text { Total number of fields of } \\
\text { selected growers }\end{array}$ & $\begin{array}{c}\text { Number of } \\
\text { sampled fields }\end{array}$ & $\begin{array}{c}\text { Total number of } \\
\text { growers in county }\end{array}$ & $\begin{array}{c}\text { Number of } \\
\text { sampled growers }^{\mathrm{y}}\end{array}$ & $\begin{array}{l}\text { Total number of sampled } \\
\text { fields in season }{ }^{\mathrm{z}}\end{array}$ \\
\hline \multirow{6}{*}{$\begin{array}{r}\text { Spring } \\
2015\end{array}$} & Bamberg & 262 & 13 & 4 & 6 & 4 & 21 \\
\hline & Barnwell & 379 & 7 & 5 & 6 & 5 & \\
\hline & Beaufort & 273 & 11 & 4 & 3 & 2 & \\
\hline & Clarendon & 103 & 1 & 1 & 1 & 1 & \\
\hline & Colleton & 285 & 14 & 4 & 4 & 2 & \\
\hline & Hampton & 211 & 3 & 3 & 5 & 3 & \\
\hline \multirow{7}{*}{$\begin{array}{r}\text { Spring } \\
2016\end{array}$} & Allendale & 102 & 3 & 1 & 4 & 1 & 24 \\
\hline & Bamberg & 262 & 13 & 4 & 17 & 3 & \\
\hline & Barnwell & 379 & 8 & 6 & 9 & 5 & \\
\hline & Beaufort & 273 & 4 & 4 & 2 & 2 & \\
\hline & Clarendon & 103 & 4 & 2 & 4 & 2 & \\
\hline & Colleton & 285 & 23 & 4 & 4 & 3 & \\
\hline & Hampton & 211 & 7 & 3 & 6 & 3 & \\
\hline \multirow{6}{*}{$\begin{array}{l}\text { Fall } \\
2016\end{array}$} & Allendale & 102 & 3 & 1 & 1 & 1 & 11 \\
\hline & Bamberg & 262 & 2 & 2 & 4 & 2 & \\
\hline & Barnwell & 379 & 1 & 1 & 1 & 1 & \\
\hline & Beaufort & 273 & 5 & 2 & 2 & 1 & \\
\hline & Colleton & 285 & 6 & 3 & 2 & 2 & \\
\hline & Hampton & 211 & 3 & 2 & 1 & 1 & \\
\hline
\end{tabular}

w Based on USDA, NASS Vegetables Summary 2014.

$\mathrm{x}$ The number of sampled fields in a county was calculated using proportional allocation based on the watermelon acreage in the county. Fields were chosen randomly from all fields of a selected grower.

y The sampled growers were chosen randomly from a list of all growers in a county.

${ }^{z}$ The total number of fields to be sampled in a season was predefined at the beginning of each sampling season. 
sampled in both spring 2015 and 2016; one was sampled in both seasons of 2016; and the remaining fields were sampled only in one season.

Randomly selected fields represented the second level of clustering in the sampling design. The number of fields sampled per county was assigned using proportional allocation based on the watermelon acreage per county (Rao 2000). If a grower had one watermelon field, that field was sampled; if the grower had two fields, one was chosen randomly; if the grower had three or four fields, two were chosen randomly; and if the grower had five or more fields, three were chosen randomly (Table 1). In the spring of 2015 , leaves were collected from a total of 21 fields, in the spring of 2016 from 24 fields, and in the fall of 2016 from 11 fields (Table 1). All fields were sampled within 1 week of harvest starting or ending.

In each field, the sampling area of $2,500 \mathrm{~m}^{2}(0.62 \mathrm{ac})$ was delimited by a diamond shape consisting of four perpendicular transects $50 \mathrm{~m}$ in length. The location was chosen away from the edges of the field if possible. Along each transect, five leaves with spots were collected at each of five sampling points spaced $10 \mathrm{~m}$ apart, resulting in a total of 20 sampling points and 100 leaves collected per field. Additional information about previous crop, fruit type, field size, transplanting date, first harvest date, and fungicides applied within 7 days and within 7 to 14 days prior to sampling was obtained from growers. Field alignment was determined with a compass and saved for each field. To prevent confounding the factor county with sampling date and plant age, samples from at least two counties were taken on any given sampling day in spring and fall of 2016.

Leaf observations. Leaves from each sampling point were placed in a separate plastic bag and transferred to a cooler after sampling of a field was completed. Upon arrival at the laboratory, bags with leaves from 1 to 2 fields were incubated under constant light and high relative humidity for 12 to $25 \mathrm{~h}$. Remaining samples were stored at $8^{\circ} \mathrm{C}$. All leaves collected on one sampling day were examined within $72 \mathrm{~h}$ after collection. Leaves were examined with a stereomicroscope at 7 to $45 \times$ magnification, and reproductive structures observed were used for identification of pathogens. Presence of pathogens was recorded for each leaf. When no pathogens could be identified on any leaf from a sampling point, pathogen isolation was attempted for one lesion from each of four leaves per sampling point as described previously (Rennberger et al. 2018). When pathogens were isolated from a leaf, they were counted as present on that leaf. For identification of powdery mildew fungi, conidia of three isolates from each of spring 2015 and spring 2016 and of two isolates of fall 2016 were mounted in $3 \%$ aqueous potassium hydroxide and examined microscopically for the presence of fibrosin bodies (Kable and Ballantyne 1963).

Data analysis. SAS (SAS Institute Inc., Cary, NC) statistical software was used for all analyses. The county a given sample was collected from was specified as stratum variable, and grower was specified as cluster variable. A map with the geographical locations of all fields sampled for this study can be found in Rennberger et al. (2018). The incidence of a pathogen was the response variable, and proportions were estimated separately for each pathogen. PROC SURVEYLOGISTIC was used to obtain estimates for the effects of county, previous crop, fruit type, field size, plant age, sampling date, field alignment, and fungicide applications. Crops grown in the sampled fields within the past season were classified into five groups: cucurbits, fallow, monocot grains, broadleaved row crops, and vegetables, to allow models to converge. Cucurbits included watermelon, cantaloupe, and pumpkin; grains included corn, rye, and wheat; row crops were comprised of cotton, peanut, and soybean; and vegetables included collard, southern pea, and tomato. Field alignment was the cardinal or intercardinal direction that rows in a given field were most closely aligned with, whereby opposing directions were part of the same alignment. Therefore, we included four possible levels of the factor field alignment in the analysis: north-south, west-east, northwest-southeast, and northeast-southwest. The effects of application of any fungicide compared with no fungicide were analyzed. A separate analysis was run for each factor to avoid issues of multicollinearity among factors and overfitting the model. Sampling weights were specified to account for the probability of choosing a particular field. They were calculated with the following formula: $w=1 /\left[\left(a^{*} b\right) /\left(c^{*} d\right)\right]$, where $a=$ the number of selected growers within a county, $b=$ number of selected fields within the county in $a, c=$ total number of growers of the county in $a$, and $d=$ total number of fields of the growers in the county in $a$ (Table 1). Estimates for probability of pathogen occurrence among counties sampled, field alignments, and fungicide applications could be obtained only for 2015 and spring 2016, because the sample size in fall 2016 was not sufficiently large.

\section{Results}

Differences among counties. There was a significant effect of county on the occurrence of all pathogens in $2015(P<0.0001)$ and on the proportion of leaves with no pathogens $(P=0.002)$ (Fig. 1). In 2015, Stagonosporopsis spp. was the most prevalent pathogen in all counties except Barnwell County, in which $P$. xanthii was the most prevalent pathogen. The estimated probability of occurrence of Stagonosporopsis spp. in Clarendon and Hampton counties was significantly higher than in all other counties. Barnwell and Beaufort had the lowest occurrence of this pathogen and did not statistically differ from each other. C. citrullina did not occur in Barnwell and Beaufort counties. In the remaining counties, its estimated probability of occurrence was significantly lower in Bamberg County than in Clarendon and Hampton counties. The estimated probability of the occurrence of $P$. xanthii in Clarendon County was significantly lower than in all other counties. The highest occurrences of powdery mildew were found in Bamberg, Barnwell, and Hampton counties. In these counties, the estimates were significantly higher than in Beaufort and Colleton counties (Fig. 1). P. cubensis was absent in Barnwell and Clarendon counties. There was no significant difference in the occurrence of $P$. cubensis among the other four counties.

In spring 2016, occurrence of Stagonosporopsis spp. and leaves with no pathogens did not differ significantly among the sampled counties $(P \geq 0.2013)$. The estimated probability of occurrence of C. citrullina in Bamberg County was significantly higher than in all other counties with the exception of Clarendon and Colleton counties. C. orbiculare was absent in Allendale and Hampton counties. In Barnwell and Beaufort counties, the estimated probability of this pathogen was very low, $1.8 \%$ and $0.5 \%$, respectively. The estimated probability of occurrence of $C$. orbiculare in Clarendon County was significantly higher than in all other counties except Colleton County. In Barnwell County, the estimate was statistically equal to that of Colleton County and significantly higher than in Allendale, Bamberg, Beaufort, and Hampton counties. P. xanthii was the most prevalent pathogen in Beaufort and Hampton counties. The estimated probability of occurrence in those two counties was significantly higher than in all other counties except Bamberg County (Fig. 1).

Previous crops. In each season, there were significant differences in the probability of occurrence of $C$. citrullina among the five categories of crops planted in the season prior to sampling (Table 2). However, differences among crops were not consistent across seasons. In spring 2015 and 2016, the estimated probability of occurrence of Cercospora leaf spot was greater after row crops than any other crop rotation except cucurbits in 2015. In spring and fall 2016, C. citrullina was found more frequently on watermelon crops planted after fallow than after cucurbit or vegetable rotations. In spring 2016, C. orbiculare was significantly more likely to occur in fields previously cropped to grains and row crops than in fields previously cropped to cucurbits or vegetables. In 2015, $P$. cubensis was significantly less likely to occur in fields cropped to vegetables prior to the sampling season compared with all other previous crops. In spring 2016, $P$. xanthii was more likely to be observed in fields with a previous cucurbit crop than in fields planted to grain or row crops in the preceding season. In fall 2016, it was significantly more likely to occur in fields that lay fallow than in fields previously cropped to cucurbits. Throughout all three seasons, Stagonosporopsis spp. were significantly more likely to occur in fields that were cropped to cucurbits or were fallow the previous season than in rotated 
fields. Stagonosporopsis spp. was least likely to occur in fields with a previous vegetable crop. In 2015 and spring 2016, leaves with no pathogens were least likely to be collected in fields that had been cropped to cucurbits compared with fields cropped to vegetables, grains, or row crops. In fall 2016, leaves with no pathogens were significantly less likely to be found in fields that were cropped to vegetables or lay fallow in the previous season compared with fields in which cucurbits were cultivated the previous season (Table 2).

Ploidy level of cultivars. The difference in susceptibility of diploid cultivars versus triploid cultivars was analyzed for 2015 and spring 2016 only, because no fields with diploid cultivars were sampled in fall 2016. In 2015, diploid cultivars were more than three times as likely to be affected by $C$. citrullina than triploid cultivars $(P=0.0005)$. In spring 2016 , there was a similar trend, but the effect was not significant $(P=0.29)$. In spring $2016, C$. orbiculare was more than four times as likely to occur on diploid cultivars than triploid cultivars $(P=0.0349)$. C. orbiculare was not detected in 2015. In $2015, P$. cubensis was more than twice as likely to occur in fields with diploid cultivars $(P=0.0381)$. $P$. cubensis was not found in fields sampled in spring 2016. In both years, the estimated probability of occurrence for P. xanthii and Stagonosporopsis spp. did not differ significantly between diploid and triploid cultivars $(P \geq 0.38$ and $P \geq 0.17$, respectively). In spring 2016, it was more likely for pathogens to be absent on leaves sampled from triploid cultivars than diploid cultivars $(P=0.0007)$. In 2015 , there was a similar trend with higher estimates for triploid cultivars, but the difference was not significant $(P=0.72)$ (Table 3$)$.

Field size. In fall 2016, estimates of pathogen occurrence decreased significantly with increasing field size for Stagonosporopsis spp. $(P=0.0085)$, viral diseases $(P=0.0018)$, and leaves with no pathogens $(P=0.0097)$, while there was a significant increase in the estimate for the occurrence of Myrothecium s.l. $(P=0.0025)$ with increasing field size. For $P$. xanthii, there was a similar trend of a decreased likelihood of occurrence in larger fields $(P=0.0572)$. Both in 2015 and spring 2016, there were no significant effects of field size on the estimated probability of occurrence of any of the observed foliar pathogens $(P \geq 0.19$ and $P \geq 0.37$, respectively) or leaves with no pathogens $(P=0.28$ and $P=0.13$, respectively). Estimates for the presence of all pathogens in both seasons were negative, whereas estimates were positive for the occurrence of leaves with no pathogens, indicating that with increasing field size the occurrence of foliar pathogens tended to decrease, whereas estimates increased for leaves with no pathogens (Table 4).
A

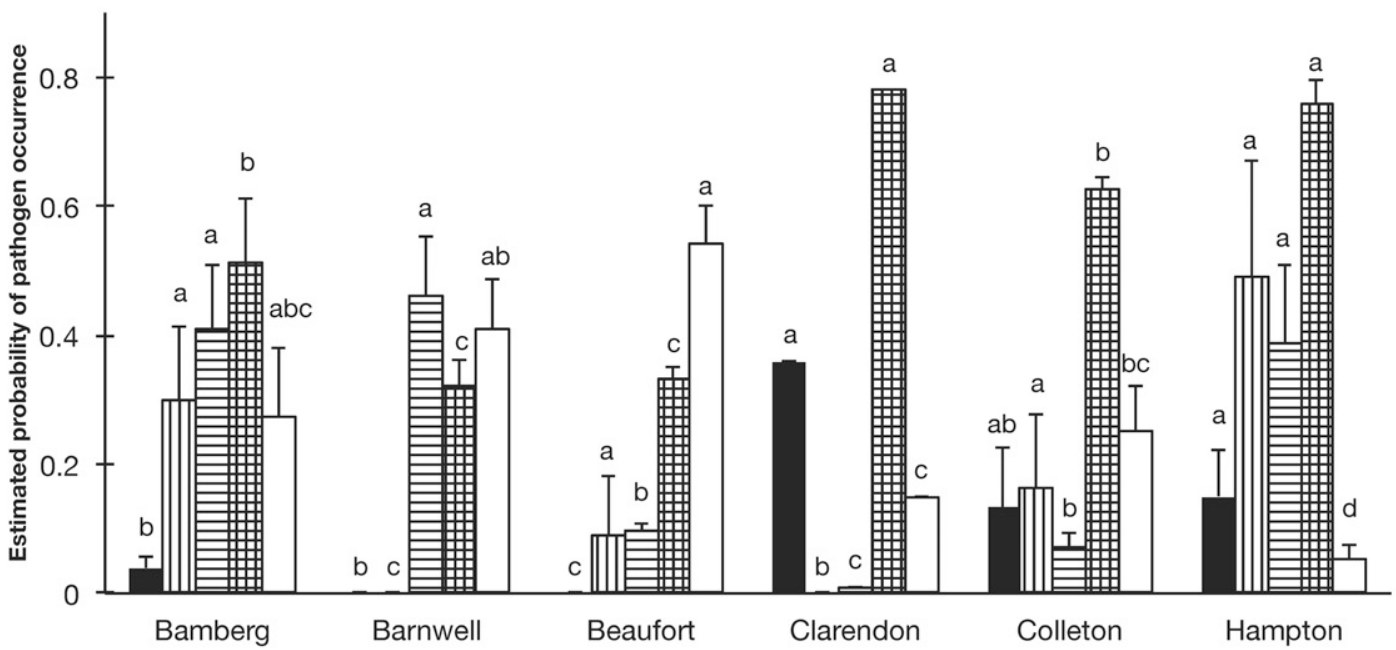

B

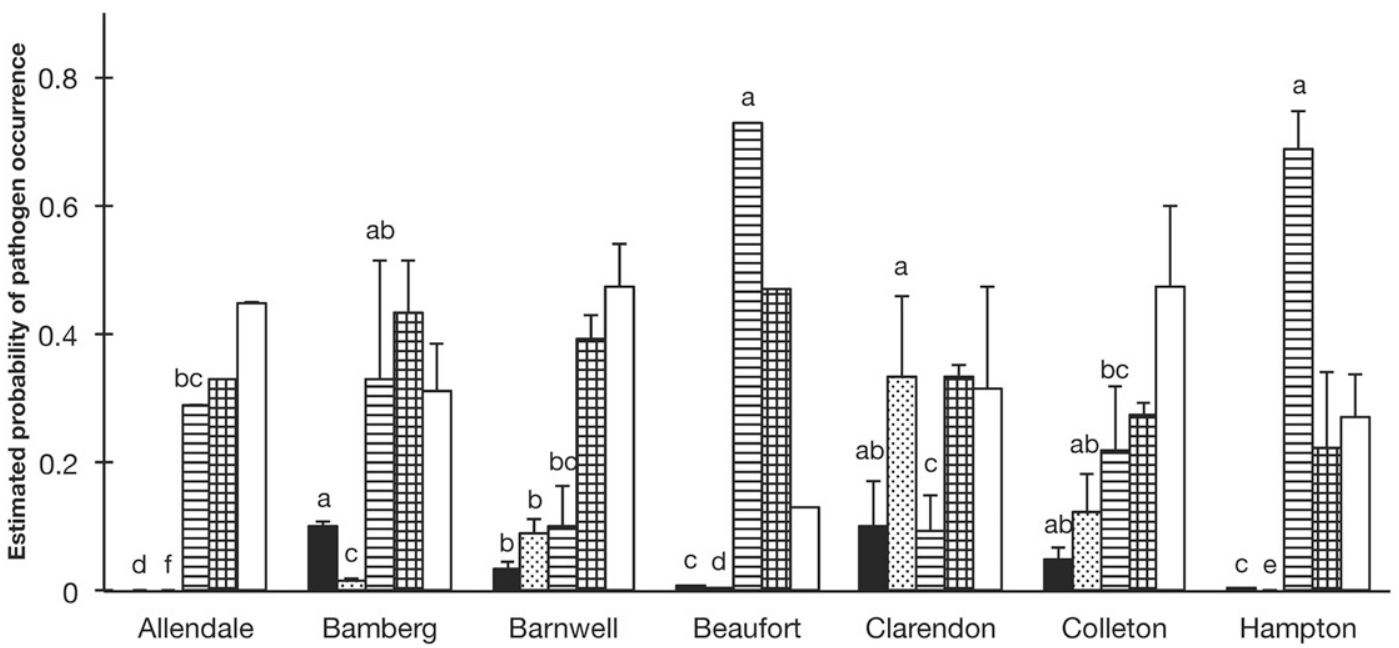

- C. citrullina

๓ $P$. cubensis

日P. xanthii

$\boxplus$ Stagonosporopsis spp.

$\square$ No pathogens

\author{
C. citrullina \\ 曰C. orbiculare \\ 日P. xanthii
}

$\boxplus$ Stagonosporopsis spp.

$\square$ No pathogens

Fig. 1. Estimated probability of pathogen occurrence by county compared within pathogen across counties. A, Estimates for spring 2015. B, Estimates for spring 2016 . Pseudoperonospora cubensis was observed only in spring 2015 and Colletotrichum orbiculare only in spring 2016. Error bars give one standard error calculated with SAS, PROC SURVEYMEANS. 
Plant age and sampling date. The effect of plant age could not be analyzed for 2015 because data about plant age were not collected that season. The plant age ranged from 54 to 106 days after transplanting in spring 2016 and from 27 to 73 days after transplanting in fall 2016. In spring 2016, plant age had a significant effect on the likelihood of occurrence for all pathogens except Stagonosporopsis spp. $(P=0.35)$ at the $10 \%$ significance level (Table 5). For $P$. xanthii, the effect was highly significant $(P=0.0081)$. The probability of occurrence of $C$. citrullina and $P$. xanthii increased with plant age, while that of $C$. orbiculare decreased. In fall 2016, the probability of occurrence of C. orbiculare, Myrothecium s.1., and Stagonosporopsis spp. was significantly $(P \leq 0.04)$ affected by plant age. For Myrothecium s.l. and Stagonosporopsis spp., the probability of occurrence increased with older plants; for $C$. orbiculare it decreased, as in spring 2016. In fall 2016, plant age had no effect on

Table 2. Effect of previous crops on probability of occurrence of foliar pathogens of watermelon in South Carolina

\begin{tabular}{|c|c|c|c|c|}
\hline \multirow[b]{2}{*}{ Pathogen } & \multirow[b]{2}{*}{ Crop $^{v}$} & \multicolumn{3}{|c|}{$\begin{array}{c}\text { Probability of pathogen } \\
\text { occurrence }^{w}\end{array}$} \\
\hline & & $\begin{array}{l}2015 \\
\text { Spring }\end{array}$ & $\begin{array}{l}2016 \\
\text { Spring }\end{array}$ & $\begin{array}{l}2016 \\
\text { Fall }\end{array}$ \\
\hline \multirow[t]{5}{*}{ Cercospora citrullina } & Cucurbit & $0.1315 a^{x}$ & $0.0100 \mathrm{c}$ & $0.0025 \mathrm{c}$ \\
\hline & Fallow & n.a. ${ }^{y}$ & $0.0384 \mathrm{~b}$ & $0.1240 \mathrm{a}$ \\
\hline & Grain & $0.0377 \mathrm{~b}$ & $0.0033 \mathrm{~d}$ & n.a. \\
\hline & Row crop & $0.0977 \mathrm{a}$ & $0.0939 \mathrm{a}$ & n.a. \\
\hline & Vegetable & $0.0000 \mathrm{c}$ & $0.0055 \mathrm{~cd}$ & $0.0181 \mathrm{~b}$ \\
\hline Probability & & $<0.0001$ & $<0.0001$ & 0.0303 \\
\hline \multirow[t]{5}{*}{ Colletotrichum orbiculare } & Cucurbit & n.d. ${ }^{\mathrm{z}}$ & $0.0200 \mathrm{~b}$ & $0.0400 \mathrm{a}$ \\
\hline & Fallow & n.d. & $0.0000 \mathrm{c}$ & $0.0000 \mathrm{c}$ \\
\hline & Grain & n.d. & $0.0687 \mathrm{a}$ & n.a. \\
\hline & Row crop & n.d. & $0.0713 \mathrm{a}$ & n.a. \\
\hline & Vegetable & n.d. & $0.0194 \mathrm{~b}$ & $0.0083 \mathrm{~b}$ \\
\hline Probability & & n.d. & $<0.0001$ & 0.0013 \\
\hline \multirow{5}{*}{$\begin{array}{l}\text { Pseudoperonospora } \\
\text { cubensis }\end{array}$} & Cucurbit & $0.4647 \mathrm{a}$ & n.d. & n.d. \\
\hline & Fallow & n.a. & n.d. & n.d. \\
\hline & Grain & $0.4074 \mathrm{a}$ & n.d. & n.d. \\
\hline & Row crop & $0.1990 \mathrm{a}$ & n.d. & n.d. \\
\hline & Vegetable & $0.0000 \mathrm{~b}$ & n.d. & n.d. \\
\hline Probability & & $<0.0001$ & n.d. & n.d. \\
\hline \multirow[t]{5}{*}{ Podosphaera xanthii } & Cucurbit & $0.1696 \mathrm{c}$ & $0.6600 \mathrm{a}$ & $0.0925 \mathrm{~b}$ \\
\hline & Fallow & n.a. & $0.5316 \mathrm{ab}$ & $0.9120 \mathrm{a}$ \\
\hline & Grain & $0.4843 \mathrm{a}$ & $0.1544 \mathrm{~b}$ & n.a. \\
\hline & Row crop & $0.1600 \mathrm{c}$ & $0.3364 \mathrm{~b}$ & n.a. \\
\hline & Vegetable & $0.3000 \mathrm{~b}$ & $0.2555 \mathrm{~b}$ & $0.0000 \mathrm{c}$ \\
\hline Probability & & 0.0408 & 0.0023 & 0.0005 \\
\hline \multirow[t]{5}{*}{ Stagonosporopsis spp. } & Cucurbit & $0.6571 \mathrm{a}$ & $0.7400 \mathrm{a}$ & $0.8075 \mathrm{a}$ \\
\hline & Fallow & n.a. & $0.7268 \mathrm{a}$ & $0.8300 \mathrm{a}$ \\
\hline & Grain & $0.3927 \mathrm{bc}$ & $0.3264 \mathrm{~b}$ & n.a. \\
\hline & Row crop & $0.4564 \mathrm{~b}$ & $0.4040 \mathrm{~b}$ & n.a. \\
\hline & Vegetable & $0.2901 \mathrm{c}$ & $0.2079 \mathrm{c}$ & $0.4461 \mathrm{~b}$ \\
\hline Probability & & $<0.0001$ & $<0.0001$ & 0.0143 \\
\hline \multirow[t]{5}{*}{ Leaves with no pathogens } & Cucurbit & $0.0554 \mathrm{c}$ & $0.1101 \mathrm{c}$ & $0.1750 \mathrm{~b}$ \\
\hline & Fallow & n.a. & $0.1621 b c$ & $0.0120 \mathrm{c}$ \\
\hline & Grain & $0.2377 \mathrm{~b}$ & $0.5071 \mathrm{a}$ & n.a. \\
\hline & Row crop & $0.3778 \mathrm{ab}$ & $0.2986 \mathrm{~b}$ & n.a. \\
\hline & Vegetable & $0.4600 \mathrm{a}$ & $0.5506 \mathrm{a}$ & $0.3206 \mathrm{a}$ \\
\hline Probability & & 0.0007 & $<0.0001$ & 0.0490 \\
\hline
\end{tabular}

${ }^{v}$ Cucurbits included watermelon, cantaloupe, and pumpkin. Grains included rye, wheat, and corn. Row crops included cotton, peanut, and soybean. Vegetables included collard, southern pea, and tomato. In fall 2016, tomato was the only previous vegetable crop.

${ }^{w}$ Probabilities of pathogen occurrence were least squares means calculated in SAS PROC SURVEYLOGISTIC

${ }^{x}$ Mean separation letters are based on $P$ values computed for least squared means.

${ }^{\mathrm{y}}$ n.a. $=$ Rotation crop was not present in sampled fields in the given season.

$\mathrm{z}$ n.d. = Pathogen was not detected in the given season . the occurrence of $C$. citrullina $(P=0.40)$. In both seasons, the likelihood of observing leaves with no pathogens decreased with increasing plant age. In spring 2016, the effect was slightly significant $(P=$ $0.0623)$, and in fall 2016 it was highly significant $(P=0.0044)$ (Table 5).

In 2015, there was a significant effect of sampling date on the estimated probability of occurrence of all pathogens observed $(P \leq$ $0.0315)$. The estimates for all pathogens, $C$. citrullina, $P$. cubensis, $P$. xanthii, and Stagonosporopsis spp., were positive, indicating that the later a field was sampled the higher the likelihood of pathogen occurrence (Table 6). In spring 2016, only two pathogens were significantly influenced by the sampling date. Both $C$. orbiculare $(P<$ $0.0001)$ and $P$. xanthii $(P=0.0011)$ were more likely to occur the later the fields were sampled. In fall 2016, with later sampling date, C. citrullina and $P$. xanthii decreased in occurrence. In 2015 and spring 2016, later sampling dates significantly decreased the occurrence of leaves with no pathogens $(P \leq 0.0049)$.

Field alignment. In 2015, all pathogens were statistically least likely to occur on leaves collected from fields aligned toward southwest $(P \leq 0.0003)$, with the exceptions that Stagonosporopsis spp. were equally likely to be present on leaves collected in fields with a west to east alignment, and $P$. xanthii was equally likely to be present on leaves collected in fields aligned toward southeast (Table 7). Leaves with no pathogens were found with the highest probability in fields with a southwestern or western alignment.

In spring 2016, C. citrullina was least likely to occur in fields aligned west to east $(P<0.0001)$ (Table 7). The occurrence of Stagonosporopsis spp. in fields aligned toward west was statistically equal to fields aligned toward south and southwest $(P=0.0993)$, and $P$. xanthii occurred in fields with a western alignment at an equally low level as in fields aligned toward southwest $(P<0.0001)$. In spring 2016, the occurrence of Stagonosporopsis spp., P. xanthii, and $C$. citrullina was highest or second highest in fields aligned toward southeast. These three pathogens consistently were found more frequently in fields aligned southeast than in fields aligned toward west $(P \leq 0.10)$. In spring 2016 , leaves with no pathogens were significantly more likely to occur in fields aligned toward west than any other direction (Table 7).

Fungicides. Of the 20 fungicide active ingredients applied during the three seasons, mancozeb and tebuconazole were applied every season and during both time intervals relative to sampling (Table 8). In 2015 and spring 2016, no fungicides were applied to five and six fields during both time intervals, respectively. In each of 2015 and spring 2016, there were four fields where no fungicides were applied during the first time interval $\leq 7$ days prior to sampling. In spring 2016, there were three fields to which no fungicides were applied during the second time interval 7 to 14 days prior to sampling. In fall 2016, there was only one field where no fungicides were sprayed during the first time interval prior to sampling. The effect of fungicide applications on the occurrence of pathogens was analyzed by comparing fields in which any fungicides were applied to fields in which no fungicides were applied. The analysis was done for fungicides that were applied in two time periods, $\leq 7$ days prior to sampling and 7 to 14 days prior to sampling. For fall 2016, the effect of all fungicides compared with no fungicides could not be analyzed for the time period 7 to 14 days prior to sampling, because all but one field were treated with fungicides in that time period.

In 2015 , for the time period $\leq 7$ days prior to sampling, $P$. cubensis, C. citrullina, and Stagonosporopsis spp. were much less likely $(P \leq 0.0067)$ to be observed in fields treated with fungicides compared with fields where no fungicides were applied (Table 9). Downy mildew was eight times, and gummy stem blight was two times, more likely to occur in fields not sprayed than in fields in which fungicides were applied. Cercospora leaf spot was not detected in fields receiving fungicides within 7 days of sampling. Fungicides applied 7 to 14 days prior to sampling also reduced the probability of occurrence of Stagonosporopsis spp. by almost one-half compared with fields not treated with fungicides during this time period $(P<0.0001)$.

In spring $2016, P$. xanthii was less likely $(P=0.0633)$ to be observed in fields where fungicides were applied for the time period 
$\leq 7$ days prior to sampling, and Stagonosporopsis spp. was less likely to be observed in fields treated with fungicides 7 to 14 days prior to sampling $(P=0.0885)$ than in fields not treated with any fungicides. There were no significant effects of application of any fungicide on any other pathogen. The likelihood of observing leaves with no pathogens was significantly $(P \leq 0.0125)$ lower in fields treated with no fungicides in both seasons for both time periods, with the exception of the period 7 to 14 days prior to sampling in spring 2016 when there was no significant effect $(P=0.46)$.

\section{Discussion}

In this study, we used logistic regression to analyze the effects of environmental and management factors on the occurrence of foliar pathogens on watermelon. A large dataset based on 5,599 watermelon leaves collected from 56 fields in 7 counties and 3 seasons was obtained using a stratified two-stage cluster sampling approach. To the best of our knowledge, this is the first study examining the influence of various factors on foliar pathogens of watermelon with data collected from commercial fields. Among the many factors we analyzed, there was a consistent increased likelihood of occurrence of Stagonosporopsis spp. in fields with a previous cucurbit crop, a lower observed occurrence of some pathogens on triploid cultivars compared with diploid cultivars, increasing probabilities of pathogen occurrence with increasing plant age, a decrease in probability of pathogen occurrence in fields aligned toward southwest or west, and a significant influence of fungicide applications on pathogen occurrences. The county in which a given field was located had a clear effect on pathogen occurrence, and field size was a significant factor only in fall 2016.

While there were a few consistencies in the occurrence of pathogens by county, like low occurrence of $P$. xanthii in both seasons in Clarendon County (Fig. 1A and B), overall the occurrence fluctuated greatly among counties between the two seasons. Peterson and Campbell (2002) observed similar differences in the occurrence of foliar pathogens of cucumber among counties and seasons in North
Carolina. This indicates that while the location of a watermelon field can have an influence on the spectrum and quantity of pathogens found in the field, geographic location alone is insufficient to predict pathogen occurrence. Oerke et al. (2010) found that the mode of dispersal had a strong influence on the distribution of Fusarium head blight pathogens. Species that relied on splash-dispersal were aggregated, and species that depended on wind dispersal had random distribution patterns. This most likely also applies to wind-dispersed foliar pathogens of cucurbits, such as Stagonosporopsis spp., $P$. cubensis, $P$. xanthii, and $C$. citrullina. The probability of occurrence for $P$. cubensis in a given cucurbit field is directly proportional to the number of viable spores in the air surrounding the field. Apart from spore production and release from the source and their survival during transport, the number of viable spores reaching a new field with susceptible cucurbit host plants depends on wet deposition, which in turn depends on precipitation (Isard et al. 2005; Neufeld et al. 2018; Viljanen-Rollinson et al. 2007). As opposed to other environmental factors, rainfall can be heterogeneous at small spatial scales (Kirchner 2006). Neufeld et al. (2018) presume this heterogeneity in rainfall to be one of several reasons for errors in predicting cucurbit downy mildew with an aerobiological model they developed. Similarly, heterogeneous rainfall leading to different levels of wet deposition of pathogen propagules, as well as differences in the length of leaf wetness periods, might be a possible explanation for the fluctuations of pathogen occurrence observed in the current study.

Stagonosporopsis spp. was significantly more likely to occur in fields that were cropped to cucurbits the preceding season than in fields planted to any other crop. This is most likely due to inoculum that persisted in colonized cucurbit debris and subsequently infected the crops planted the following season. In an earlier study on the effect of crop rotation on the severity of gummy stem blight in cucumbers, breaking a continuous cycle of cucumber cropping reduced the severity of gummy stem blight on cucumber foliage. Disease severity was further reduced with increasing time intervals between two cucumber crops. The type of cucurbit crop or the sequence of crops

Table 3. Comparison of probabilities of pathogen occurrence on diploid versus triploid watermelon cultivars at the time of sampling in the spring of 2015 and $2016^{\mathrm{y}}$

\begin{tabular}{|c|c|c|c|c|c|c|}
\hline \multirow[b]{2}{*}{ Pathogen } & \multicolumn{3}{|c|}{2015} & \multicolumn{3}{|c|}{2016} \\
\hline & Diploid & Triploid & $P$-value & Diploid & Triploid & $P$-value \\
\hline C. citrullina & 0.1389 & 0.0434 & 0.0005 & 0.0965 & 0.0650 & 0.2945 \\
\hline C. orbiculare & n.d. ${ }^{\mathrm{z}}$ & n.d. & n.d. & 0.2082 & 0.0481 & 0.0349 \\
\hline P. cubensis & 0.3187 & 0.1314 & 0.0381 & n.d. & n.d. & n.d. \\
\hline P. xanthii & 0.2443 & 0.2178 & 0.7083 & 0.4470 & 0.3045 & 0.3849 \\
\hline Stagonosporopsis spp. & 0.5246 & 0.5097 & 0.8685 & 0.4920 & 0.3589 & 0.1716 \\
\hline No Pathogens & 0.2855 & 0.3356 & 0.7194 & 0.1160 & 0.3781 & 0.0007 \\
\hline
\end{tabular}

y Values are least squared means obtained from logistic regression and represent probabilities of pathogen occurrence.

${ }^{\mathrm{z}}$ n.d. = Pathogen was not detected in the given year.

Table 4. Effect of watermelon field size on pathogen occurrence at the time of sampling in South Carolina from 2015 to 2016

\begin{tabular}{|c|c|c|c|c|c|c|c|c|c|}
\hline \multirow[b]{2}{*}{ Pathogen } & \multicolumn{2}{|c|}{2015 Spring } & \multirow[b]{2}{*}{$P$-value } & \multicolumn{2}{|c|}{2016 Spring } & \multirow[b]{2}{*}{$P$-value } & \multicolumn{2}{|c|}{2016 Fall } & \multirow[b]{2}{*}{$P$-value } \\
\hline & Estimate $^{y}$ & Standard error & & Estimate & Standard error & & Estimate & Standard error & \\
\hline C. citrullina & -0.0234 & 0.0298 & 0.4495 & -0.0123 & 0.0184 & 0.5143 & -0.0332 & 0.0127 & 0.1202 \\
\hline C. orbiculare & n.d. ${ }^{\mathrm{z}}$ & n.d. & n.d. & -0.0272 & 0.0413 & 0.5228 & -0.0437 & 0.0223 & 0.1890 \\
\hline Myrothecium s.1. & n.d. & n.d. & n.d. & n.d. & n.d. & n.d. & 0.2931 & 0.0147 & 0.0025 \\
\hline P. cubensis & -0.0355 & 0.0251 & 0.1850 & n.d. & n.d. & n.d. & n.d. & n.d. & n.d. \\
\hline P. xanthii & -0.0200 & 0.0171 & 0.2661 & -0.0283 & 0.0369 & 0.4573 & -0.0891 & 0.0223 & 0.0572 \\
\hline Stagonosporopsis spp. & -0.0045 & 0.0122 & 0.7205 & -0.0095 & 0.0101 & 0.3694 & -0.0441 & 0.0041 & 0.0085 \\
\hline Virus & n.d. & n.d. & n.d. & n.d. & n.d. & n.d. & -0.2368 & 0.0099 & 0.0018 \\
\hline Leaves with no pathogens & 0.0122 & 0.0108 & 0.2820 & 0.0282 & 0.0173 & 0.1292 & -0.0081 & 0.0008 & 0.0097 \\
\hline
\end{tabular}

${ }^{y}$ Maximum likelihood estimates represent percent change in probability of pathogen occurrence per unit increase in field size $(1 \mathrm{ac}=0.40$ ha $)$. Negative estimates indicate a decrease in the probability of pathogen occurrence with increasing field size. Positive estimates indicate an increase in the probability of pathogen occurrence with increasing field size.

${ }^{\mathrm{z}}$ n.d. = Pathogen was not detected in the given year. 
in the rotation did not influence disease severity (Sitterly 1969). Similarly, leaves with no pathogens were less frequently found in fields rotated to vegetables or grains than in fields cropped to cucurbits or left fallow in the prior season. In studies in which colonized cucumber and watermelon vines were buried, the pathogen could be recovered 9 and 7 months after burial, respectively (Keinath 2002; Van Steekelenburg 1983). The depth at which colonized watermelon vines were buried had only a minor effect on the recovery of Stagonosporopsis spp. (Keinath 2002). S. citrulli can survive up to 103 weeks on infested muskmelon debris left on the soil surface, a time period sufficiently long to facilitate carryover of inoculum into crops planted up to two seasons after the original crop is finished (Keinath 2008). Therefore, it is not surprising that a previous cucurbit crop increases the risk of gummy stem blight epidemics in watermelon crops. Growers should thus adopt a crop rotation of at least 2 years between cucurbit crops and, at a minimum, avoid planting cucurbits after cucurbits. It remains unknown why watermelons planted into fields that lay fallow the previous season also had an increased likelihood of being affected by gummy stem blight. A possible explanation might be cucurbitaceous weeds serving as hosts during fallowing. Cucurbit species native to North America, like Cucurbita digitata and Melothria scabra, and introduced species, like Ecballium elaterium and Cucumis anguria, an invasive species that has been reported as a noxious weed in peanuts in the southeastern United States, have all been confirmed to be moderately to highly susceptible to $S$. citrulli, the most common species causing gummy stem blight in the southeastern United States (Buchanan et al. 1981; Rennberger and Keinath 2018).

While the disease-increasing effect of a previous cucurbit crop on gummy stem blight is plausible and expected, the effect on the occurrence of powdery mildew and downy mildew was somewhat unexpected. Rotation to vegetable crops, which included collard, southern pea, or tomato, reduced the estimates for leaves with powdery or downy mildew in 2016 and 2015 , respectively. It is possible

Table 5. Effect of plant age at the time of sampling on the probability of occurrence of foliar pathogens of watermelon in two seasons in South Carolina ${ }^{\mathrm{x}}$

\begin{tabular}{|c|c|c|c|c|c|c|}
\hline \multirow[b]{2}{*}{ Pathogen } & \multicolumn{3}{|c|}{2016 Spring } & \multicolumn{3}{|c|}{2016 Fall } \\
\hline & Estimate $^{\mathrm{y}}$ & Standard error & $P$-value & Estimate & Standard error & $P$-value \\
\hline C. citrullina & 0.0501 & 0.0244 & 0.0620 & -0.0149 & 0.0141 & 0.4014 \\
\hline C. orbiculare & -0.0710 & 0.0364 & 0.0751 & -0.0320 & 0.0068 & 0.0424 \\
\hline Myrothecium s.l. & n.d. ${ }^{z}$ & n.d. & n.d. & 0.0538 & 0.0077 & 0.0198 \\
\hline P. xanthii & 0.0929 & 0.0293 & 0.0081 & 0.4958 & 0.1487 & 0.0794 \\
\hline Stagonosporopsis spp. & 0.0086 & 0.0088 & 0.3465 & 0.0101 & 0.0018 & 0.0304 \\
\hline No pathogens & -0.0360 & 0.0175 & 0.0623 & -0.0347 & 0.0023 & 0.0044 \\
\hline
\end{tabular}

${ }^{x}$ The effect of plant age could not be analyzed for spring 2015 because no data on planting dates were collected that season.

${ }^{y}$ Maximum likelihood estimates represent percent change in probability of pathogen occurrence per unit increase in time (1 day). Negative estimates indicate a decrease in the probability of pathogen occurrence with increasing plant age. Positive estimates indicate an increase in the probability of pathogen occurrence with increasing plant age.

${ }^{\mathrm{z}}$ n.d. = Pathogen was not detected in the given year.

Table 6. Effect of sampling date on probability of occurrence of foliar pathogens of watermelon from 2015 to 2016 in South Carolina

\begin{tabular}{|c|c|c|c|c|c|c|c|c|c|}
\hline \multirow[b]{2}{*}{ Pathogen } & \multicolumn{3}{|c|}{2015} & \multicolumn{3}{|c|}{2016 Spring } & \multicolumn{3}{|c|}{2016 Fall } \\
\hline & Estimate $^{\mathbf{y}}$ & Standard error & $P$-value & Estimate & Standard error & $P$-value & Estimate & Standard error & $P$-value \\
\hline C. citrullina & 0.0665 & 0.0270 & 0.0315 & 0.0371 & 0.0217 & 0.1134 & -0.4500 & 0.0390 & 0.0074 \\
\hline C. orbiculare & n.d. ${ }^{z}$ & n.d. & n.d. & 0.1019 & 0.0167 & $<0.0001$ & 0.0824 & 0.0502 & 0.2421 \\
\hline Myrothecium s.1. & n.d. & n.d. & n.d. & n.d. & n.d. & n.d. & 0.0016 & 0.0415 & 0.9736 \\
\hline P. cubensis & 0.0977 & 0.0349 & 0.0174 & n.d. & n.d. & n.d. & n.d. & n.d. & n.d. \\
\hline P. xanthii & 0.0973 & 0.0162 & $<0.0001$ & 0.0823 & 0.0194 & 0.0011 & -0.1600 & 0.0496 & 0.0843 \\
\hline Stagonosporopsis spp. & 0.0703 & 0.0132 & 0.0002 & -0.0018 & 0.0121 & 0.8826 & 0.0235 & 0.0231 & 0.4156 \\
\hline No pathogens & -0.1238 & 0.0128 & $<0.0001$ & -0.0587 & 0.0171 & 0.0049 & 0.0064 & 0.0201 & 0.7808 \\
\hline
\end{tabular}

${ }^{y}$ Maximum likelihood estimates represent percent change in probability of pathogen occurrence per unit increase in time (1 day). Negative estimates indicate a decrease in the probability of pathogen occurrence with increasing sampling date. Positive estimates indicate an increase in the probability of pathogen occurrence with increasing sampling date.

${ }^{\mathrm{z}}$ n.d. = Pathogen was not detected in the given year.

Table 7. Effect of field alignment on estimated probability of occurrence of foliar pathogens of watermelon in South Carolina compared within pathogen-year combinations $^{\mathrm{x}}$

\begin{tabular}{|c|c|c|c|c|c|c|}
\hline Season, year ${ }^{y}$ & Pathogen & $P$-value & South & Southeast & Southwest & West \\
\hline \multirow[t]{5}{*}{ Spring 2015} & Cercospora citrullina & $<0.0001$ & $0.1260 \mathrm{a}^{\mathrm{z}}$ & $0.0110 \mathrm{~b}$ & $0.0000 \mathrm{c}$ & $0.0919 \mathrm{a}$ \\
\hline & Podosphaera xanthii & 0.0003 & $0.3331 \mathrm{a}$ & $0.2602 a b c$ & $0.1067 \mathrm{c}$ & $0.1661 \mathrm{~b}$ \\
\hline & Pseudoperonospora cubensis & $<0.0001$ & $0.1258 \mathrm{~b}$ & $0.4522 \mathrm{a}$ & $0.0033 \mathrm{c}$ & $0.1980 \mathrm{ab}$ \\
\hline & Stagonosporopsis spp. & $<0.0001$ & $0.7461 \mathrm{a}$ & $0.4894 \mathrm{a}$ & $0.3133 \mathrm{~b}$ & $0.4119 \mathrm{ab}$ \\
\hline & No pathogens & $<0.0001$ & $0.0937 \mathrm{~b}$ & $0.3307 \mathrm{ab}$ & $0.5967 \mathrm{a}$ & $0.3825 \mathrm{a}$ \\
\hline \multirow[t]{4}{*}{ Spring 2016} & Cercospora citrullina & $<0.0001$ & $0.0666 \mathrm{a}$ & $0.1110 \mathrm{a}$ & $0.0839 \mathrm{a}$ & $0.0011 \mathrm{~b}$ \\
\hline & Podosphaera xanthii & $<0.0001$ & $0.2860 \mathrm{~b}$ & $0.7537 \mathrm{a}$ & $0.1767 \mathrm{bc}$ & $0.1241 \mathrm{c}$ \\
\hline & Stagonosporopsis spp. & 0.0993 & $0.3045 \mathrm{~b}$ & $0.4214 \mathrm{a}$ & $0.4433 \mathrm{ab}$ & $0.2854 \mathrm{~b}$ \\
\hline & No pathogens & $<0.0001$ & $0.3853 \mathrm{~b}$ & $0.0896 \mathrm{c}$ & $0.3552 \mathrm{~b}$ & $0.5910 \mathrm{a}$ \\
\hline
\end{tabular}

\footnotetext{
${ }^{\mathrm{x}}$ Values are least squared means obtained from logistic regression and represent probabilities of pathogen occurrence.

y Fall 2016 was excluded from this analysis due to the small sample size of 11 fields.

${ }^{\mathrm{z}}$ Means within rows followed by the same letter do not differ significantly at the indicated $P$-value based on least squares means calculated in SAS PROC SURVEYLOGISTIC.
} 
that fungicides applied to the vegetable crops grown in the previous years reduced overwintering of powdery mildew chasmothecia or downy mildew oospores. Although downy mildew was not reported to occur on watermelon in South Carolina in 2014, it occurred in 2013 (Anonymous 2018). The maximum survival time of oospores is unknown, but oospores of $P$. cubensis were able overwinter under conditions of $-20^{\circ} \mathrm{C}$ and infect cucumber plants the following spring (Zhang et al. 2012). Although chasmothecia of $P$. xanthii have been observed in the field in the United States, the role of chasmothecia in the epidemiology of powdery mildew is regarded as negligible (McGrath 2017). Most chasmothecia of Erysiphe necator, the causal agent of powdery mildew on grape, that remain on bark survive over winter and release viable ascospores until the following spring, while most chasmothecia that fall onto leaf litter or soil do not survive the winter (Rossi et al. 2010). Thus, it may be inferred that chasmothecia of $P$. xanthii also might not survive over winter. Further research is needed to clarify the role of chasmothecia in the epidemiology of cucurbit powdery mildew.

All pathogens analyzed in this study tended to be observed less frequently in fields planted with triploid (seedless) watermelon cultivars compared with fields planted with diploid (seeded) cultivars. For $C$. citrullina, $C$. orbiculare, and $P$. cubensis, the difference was significant in one season. No differences between cultivar types were observed for $P$. xanthii and Stagonosporopsis spp. Previously, triploid cultivars were found to be less susceptible to anthracnose, gummy stem blight, and powdery mildew in field experiments in South Carolina (Keinath and Hassel 1999 2000). The more vigorous plants of triploid cultivars compared with diploid ones was stated as a possible explanation for this observation (Keinath and Hassel 1999). In the current study, the effect of diploid versus triploid cultivars on the occurrence of foliar pathogens is confounded with the effect of field size. In 2015 and spring 2016, the average size of fields with diploid

Table 8. Fungicides applied to watermelon fields during the two-week period prior to sampling in two seasons in South Carolina

\begin{tabular}{|c|c|c|c|c|c|c|c|c|c|c|}
\hline \multirow[b]{3}{*}{ FRACCode } & \multirow{3}{*}{$\begin{array}{c}\text { Active } \\
\text { ingredient }\end{array}$} & \multirow{3}{*}{$\begin{array}{l}\text { Protective/ } \\
\text { Systemic }\end{array}$} & \multirow{2}{*}{\multicolumn{2}{|c|}{ Spring 2015}} & \multirow{2}{*}{\multicolumn{2}{|c|}{ Spring 2016}} & \multicolumn{4}{|c|}{ Specific activity against pathogens ${ }^{y}$} \\
\hline & & & & & & & \multirow[b]{2}{*}{ C. citrullina } & \multirow[b]{2}{*}{ P. xanthii } & \multirow[b]{2}{*}{ P. cubensis } & \multirow{2}{*}{$\begin{array}{c}\text { Stagonosporopsis } \\
\text { spp. }\end{array}$} \\
\hline & & & $\leq 7$ days & 7 to 14 days & $\leq 7$ days & 7 to 14 days & & & & \\
\hline$\overline{\mathrm{M}}$ & Chlorothalonil & $\mathrm{P}$ & - & + & - & + & + & + & + & + \\
\hline M & Copper & $P$ & - & + & - & + & - & - & - & - \\
\hline M & Mancozeb & $\mathrm{P}$ & + & + & + & + & + & - & + & + \\
\hline 11 & Azoxystrobin & S & - & - & + & + & + & - & - & - \\
\hline 7 & Boscalid & S & + & + & + & - & n.d. ${ }^{\mathrm{z}}$ & + & - & - \\
\hline 9 & Cyprodinil & S & - & + & + & + & - & + & - & + \\
\hline 3 & Difenoconazole & S & - & + & + & + & n.d. & + & - & + \\
\hline 12 & Fludioxonil & S & - & + & - & + & n.d. & + & - & + \\
\hline 43 & Fluopicolide & S & - & - & - & + & - & - & - & - \\
\hline 49 & Oxathiapiprolin & S & - & - & + & - & + & - & + & - \\
\hline 11 & Pyraclostrobin & $\mathrm{S}$ & + & + & + & - & n.d. & - & - & - \\
\hline 3 & Tebuconazole & S & + & + & + & + & + & - & - & + \\
\hline 1 & $\begin{array}{l}\text { Thiophanate- } \\
\text { methyl }\end{array}$ & $S$ & + & - & + & + & + & - & - & - \\
\hline 3 & Triflumizole & S & - & + & - & - & - & + & - & - \\
\hline
\end{tabular}

y Specific activity as reported in Kemble et al. (2018). A “+” indicates the fungicide was rated as having excellent, good, or fair efficacy against a given pathogen, and a ""” indicates the fungicide was rated as having poor or no efficacy.

${ }^{z}$ n.d. $=$ No data on efficacy.

Table 9. Effect of fungicide applications on the probability of pathogen occurrence on watermelon leaves at the time of sampling in three seasons in South Carolina

\begin{tabular}{|c|c|c|c|c|c|c|}
\hline \multirow[b]{2}{*}{ Season, year ${ }^{y}$} & \multirow[b]{2}{*}{ Pathogen } & \multirow[b]{2}{*}{ Fungicide group ${ }^{\mathrm{z}}$} & \multicolumn{2}{|c|}{ Up to 7 days } & \multicolumn{2}{|c|}{7 to 14 days } \\
\hline & & & $P$-value & Mean & $P$-value & Mean \\
\hline \multirow{10}{*}{ Spring, 2015} & Cercospora citrullina & None & $<0.0001$ & $0.1780 \mathrm{a}$ & 0.1376 & 0.1545 \\
\hline & & Some & & $0.0000 \mathrm{~b}$ & & 0.0795 \\
\hline & Pseudoperonospora cubensis & None & 0.0067 & $0.4428 \mathrm{a}$ & 0.2455 & 0.3411 \\
\hline & & Some & & $0.0543 \mathrm{~b}$ & & 0.1713 \\
\hline & Podosphaera xanthii & None & 0.5746 & 0.2379 & 0.2784 & 0.2705 \\
\hline & & Some & & 0.2084 & & 0.1810 \\
\hline & Stagonosporopsis spp. & None & $<0.0001$ & $0.6188 \mathrm{a}$ & $<0.0001$ & $0.7322 \mathrm{a}$ \\
\hline & & Some & & $0.2996 \mathrm{~b}$ & & $0.3923 \mathrm{~b}$ \\
\hline & No pathogens & None & $<0.0001$ & $0.1224 \mathrm{~b}$ & 0.0021 & $0.1282 \mathrm{~b}$ \\
\hline & & Some & & $0.5264 \mathrm{a}$ & & $0.3966 \mathrm{a}$ \\
\hline \multirow[t]{10}{*}{ Spring, 2016} & Cercospora citrullina & None & 0.8125 & 0.0665 & 0.4789 & 0.0799 \\
\hline & & Some & & 0.0729 & & 0.0578 \\
\hline & Colletotrichum orbiculare & None & 0.6202 & 0.0535 & 0.9807 & 0.0420 \\
\hline & & Some & & 0.0354 & & 0.0413 \\
\hline & Podosphaera xanthii & None & 0.0633 & $0.5428 \mathrm{a}$ & 0.5321 & 0.2816 \\
\hline & & Some & & $0.2227 \mathrm{~b}$ & & 0.4082 \\
\hline & Stagonosporopsis spp. & None & 0.8689 & 0.3816 & 0.0885 & $0.4471 \mathrm{a}$ \\
\hline & & Some & & 0.3944 & & $0.3097 \mathrm{~b}$ \\
\hline & No pathogen & None & 0.0125 & $0.2075 \mathrm{~b}$ & 0.4599 & 0.3133 \\
\hline & & Some & & $0.4050 \mathrm{a}$ & & 0.3683 \\
\hline
\end{tabular}

${ }^{y}$ Fall 2016 was excluded from this analysis due to the small sample size of 11 fields.

${ }^{\mathrm{z}}$ Fields treated with any fungicide were compared with fields where no fungicides were applied (none versus some). 
cultivars was 1.3 and 4.8 ha, respectively. In contrast, the average size of fields with triploid cultivars was 10.2 and 9.9 ha, respectively, in 2015 and spring 2016. Generally, there was a tendency for fewer leaves with pathogens to be observed in larger fields compared with smaller fields, although the effect of field size was significant only in fall 2016. While larger fields were more likely to be planted with a triploid cultivar, larger fields also tended to be managed more intensively than smaller fields, with more frequent fungicide applications with better equipment and more informed choices of the fungicides applied. Contrary to this finding, larger patches of host plants had higher proportions of diseased plants in a large-scale habitat corridor experiment in South Carolina that used the plant pathosystem of southern corn leaf blight (Cochliobolus heterostrophus) on sweet corn (Zea mays) as a model for wind dispersed fungal plant diseases on foliage. The greatest predictor of disease development was the distance of host plants to habitat edges (Johnson and Haddad 2011).

The factor field alignment had a consistently significant influence on the occurrence of foliar pathogens of watermelon in this study. In spring 2015 and spring 2016, fields aligned toward southwest and toward west, respectively, were significantly less likely to be affected by foliar pathogens, while the reverse was true for leaves with no pathogens. A possible explanation for this could be the direction of the wind prevailing in the sampled region. Raichle and Carson (2009) analyzed wind data from nine sites in the southeastern United States collected between 2002 and 2005 and found that the predominant wind direction in this region is from the west. Some sites had a southwest component, which the authors attributed to springtime storm systems that originate from the Gulf of Mexico. Considering the main wind direction in the southeastern United States, it seems plausible that fields aligned toward west or southwest are exposed to a greater airflow compared with fields with different alignments. This increased airflow most likely led to shorter periods of leaf wetness that were less conducive to disease development. Similar effects of field alignment have been reported in previous studies. A survey of ray blight on pyrethrum (Tanacetum cinerariifolium) in Tasmania, caused by Didymella ligulicola, found that north-facing slopes had a significantly lower disease incidence than slopes with a southerly exposure. This effect of slope direction was attributed to the extended periods of sunlight in the northerly exposed slopes, which led to a decrease of leaf wetness and ultimately minimized the infection time for the pathogen (Pethybridge and Hay 2001).

The age of the plants sampled had a significant effect on the probability of pathogen occurrence. With the exception of $C$. orbiculare, which decreased in likelihood of occurrence with increasing plant age, all other pathogens were more likely to be present the older the sampled plants were. In both seasons where the effect of plant age was analyzed, the likelihood of $P$. xanthii to be observed increased with increasing plant age. Similarly, in two seasons of a field trial with watermelon in South Carolina, powdery mildew did not start to develop until the plants were at least 99 days old (Keinath 2015c). On oilseed rape (Brassica napus), leaves of all ages showed symptoms of powdery mildew caused by Erysiphe cruciferarum, but disease onset was delayed on young plants compared with older plants and developed faster on older plants (Uloth et al. 2018). Our findings confirm previous observations in the field, but it is likely that there are other factors contributing to the increased susceptibility of older watermelon plants in the field, since $P$. xanthii readily infects watermelon seedlings in the greenhouse (Kousik et al. 2018). In accordance with our finding of decreased susceptibility of older plants to anthracnose, fruits of butternut squash become resistant to fruit rot caused by C. orbiculare as they age (Drennan and Zitter 1996). However, in a more recent study, a high percentage of watermelon fruit had symptoms of anthracnose, which suggests that watermelon fruit might remain susceptible for several weeks (Keinath 2018). As outlined by Freeman et al. (1998), anthracnose diseases can present themselves both as diseases of developing and mature plant tissues with a wide array of disease patterns in relation to the developmental stage of the host plant. Due to the nature of observational studies such as the current one, future studies specifically designed to determine the effect of plant age on cucurbit anthracnose are needed to clarify conclusively the role of this factor in the development of the disease. Although Stagonosporopsis spp. and C. orbiculare are known to be seedborne pathogens, no grower reported symptoms on transplants throughout this study (Keinath 2017a, b). It is therefore unlikely that seedborne inoculum had a substantial impact on the occurrence of these two pathogens in the present study.

The application of fungicides to the fields sampled had significant effects on the occurrence of foliar pathogens in this study. A survey of foliar pathogens on cucumbers in North Carolina did not find an influence of fungicides on the occurrence of pathogens, but the effects were not analyzed statistically (Peterson and Campbell 2002). Due to the large number of different active ingredients used, the fungicides were grouped for analysis into two categories of any fungicide versus no fungicide. In general, the effect of fungicides might have been lowered in our analysis because we recorded and analyzed disease incidence instead of disease severity. In six of eight experiments in a study that utilized a bioassay with potted cucumber plants, $\leq 50 \%$ of the tested fungicides reduced incidence of downy mildew caused by $P$. cubensis compared with the water control. This lower efficacy was due to the fact that disease incidence was a less quantitative measure than disease severity (Keinath 2016). In future survey studies of foliar cucurbit diseases, severity ratings could improve the power of the analyses.

In 2015 , fungicides applied $\leq 7$ days prior to sampling significantly reduced the occurrence of all observed pathogens except $P$. xanthii. In spring 2016, however, the pattern was reversed with $P$. xanthii as the only pathogen for which occurrence was reduced, while fungicides had no effect on the other three pathogens detected in this season. A possible explanation for this difference could be the weather conditions prevailing in the two seasons. In June and July 2015 , the rainfall in coastal South Carolina was $\geq 80 \mathrm{~mm}$ higher than in the corresponding months in 2016. The rainfall in 2015 favored pathogens that require humid conditions, while in 2016, the drier conditions favored P. xanthii (McGrath 2017; Rennberger et al. 2018). Similarly, fungicide applications reduced the occurrence of gummy stem blight in the wetter spring 2015, when the probability of occurrence in nonsprayed fields was greater than $50 \%$, but not in the drier spring of 2016, when the probability of occurrence in nonsprayed fields was similar to that in sprayed fields. Likewise, the probability of detecting $C$. citrullina and $C$. orbiculare in spring 2016 was low, even in fields that were not treated with fungicides.

In spring 2015 , the only fungicide with activity against $P$. cubensis that was applied to fields $\leq 7$ days before sampling was the protectant mancozeb (Table 2). Mancozeb protected muskmelons against cucurbit downy mildew when applied before infection occurred (Keinath et al. 2007). However, it also has been shown that mancozeb did not sufficiently control downy mildew to prevent yield loss in cucumber (Adams et al. 2015; Colucci et al. 2007). Since the present study was observational, and data of only one season could be analyzed for $P$. cubensis, additional studies are needed to determine whether protectant fungicides are effective against downy mildew on watermelon.

Compared with unsprayed fields, application of fungicides in both time periods in 2015 significantly reduced the probability of observing Stagonosporopsis spp. This beneficial effect of fungicides likely is explained by the widespread use of mancozeb and tebuconazole $\geq 7$ to 14 days before sampling and cyprodinil plus fludioxonil or difenoconazole within 14 days of sampling, since all four fungicides are moderately effective against gummy stem blight (Keinath 2001, 2015b).

Small sample sizes can lead to biased estimators in logistic regression with survey data (Graubard and Korn 2011). Therefore, the low number of significant differences regarding the effects of ploidy level, field size, and fungicide application on pathogen occurrence might have been influenced by the relatively small number of fields that could be processed due to time constraints. We avoided overfitting our models by analyzing each factor separately (Motrenko et al. 2014).

In conclusion, this study is the first to analyze the impact of environmental and management factors on the occurrence of foliar 
pathogens of watermelon with data collected from commercial farms. Our results emphasize the importance of crop rotation and timely applications of fungicides to manage foliar diseases of watermelon, particularly gummy stem blight, downy mildew, and powdery mildew. Crop age, cultivar type, and field alignment also were found to significantly influence the probability of pathogen occurrence. Carefully monitoring disease development on older crops, growing triploid cultivars, and aligning fields west to east (or southwest to southeast) also may reduce the occurrence of foliar diseases on watermelon.

\section{Acknowledgments}

We thank V. B. DuBose, C. Conrad, H. Mauk, M. Rushton, and J. Yeargin for technical assistance and the South Carolina Agricultural Society for supplying the Thomas Heyward Jr. Graduate Fellowship to G. Rennberger.

\section{Literature Cited}

Adams, M. L., Parada, C. H., and Quesada-Ocampo, L. M. 2015. Evaluation of fungicides for control of downy mildew on cucumber, Kinston I 2014. Plant Dis. Manage. Rep. 9:V081. Online publication.

Anonymous. 2018. Cucurbit Downy Mildew Forecasting. Annual Epidemic Histories. Online. Available at: http://cdm.ipmpipe.org/node/107

Brewer, M. T., Rath, M., and Li, H.-X. 2015. Genetic diversity and population structure of cucurbit gummy stem blight fungi based on microsatellite markers. Phytopathology 105:815-824.

Bruton, B. D., and Fish, W. W. 2017. Crater rot. Pages 94-96 in: Compendium of Cucurbit Diseases and Pests, 2nd Ed. A. P. Keinath, W. M. Wintermantel, and T. A. Zitter, eds. American Phytopathological Society, St. Paul, MN.

Buchanan, G. A., Hauser, E. W., and Patterson, R. M. 1981. Control of bur gherkins (Cucumis anguria) in peanuts (Arachis hypogaea) with herbicides. Peanut Sci. 8:66-73.

Cho, S. E., Park, J. H., Hong, S. H., Kim, B. S., and Shin, H. D. 2014. First report of powdery mildew caused by Podosphaera xanthii on Verbena brasiliensis in Korea. Plant Dis. 98:1159.

Colucci, S. J., Thornton, A. C., Adams, M. L., and Holmes, G. J. 2007. Delayed fungicide application to cucumber and the effects on downy mildew severity and yield, 2006. Plant Dis. Manage. Rep. 1:V107. Online publication.

Drennan, J. L., and Zitter, T. A. 1996. Effects of rind maturity and wounding on disease caused by Didymella bryoniae, Colletotrichum orbiculare, and Rhizoctonia solani on butternut squash and pumpkin. (Abstr.) Phytopathology 86:S121

Everts, K., and Himmelstein, P. 2010. Disease management for organic vegetable farms, Chapter 6. Organic Vegetable Production Manual. Online, Available at https://extension.umd.edu/mdvegetables/organic-vegetable-production/ organic-vegetable-production-manual

Everts, K. L. 2017. Cercospora leaf spot. Page 56 in: Compendium of Cucurbit Diseases and Pests, 2nd Ed. A. P. Keinath, W. M. Wintermantel, and T. A. Zitter, eds. American Phytopathological Society, St. Paul, MN.

Everts, K. L., Korir, R. C., and Newark, M. J. 2016. Re-evaluation of MelCast for fungicide scheduling in mid-Atlantic watermelon. Plant Health Prog. 17:51-52.

Freeman, S., Katan, T., and Shabi, E. 1998. Characterization of Colletotrichum species responsible for anthracnose diseases of various fruits. Plant Dis. 82: 596-605.

Graubard, B. I., and Korn, E. 2011. Conditional logistic regression with survey data. Stat. Biopharm. Res. 3:398-408.

Groenewald, J. Z., Nakashima, C., Nishikawa, J., Shin, H.-D., Park, J.-H., Jama, A. N., Groenewald, M., Braun, U., and Crous, P. W. 2013. Species concepts in Cercospora: Spotting the weeds among the roses. Stud. Mycol. 75:115-170.

Gugino, B. K., Carroll, J. E., Widmer, T. L., Chen, P., and Abawi, G. S. 2007. An IPM program for managing fungal leaf blight diseases of carrot in New York. Plant Dis. 91:59-65.

Hao, J., Subbarao, K. V., and Koike, S. T. 2003. Effects of broccoli rotation on lettuce drop caused by Sclerotinia minor and on the population density of sclerotia in soil. Plant Dis. 87:159-166.

Isard, S. A., Gage, S. H., Comtois, P., and Russo, J. M. 2005. Principles of the atmospheric pathway for invasive species applied to soybean rust. Bioscience 55:851-861.

Johnson, B. L., and Haddad, N. M. 2011. Edge effects, not connectivity determine the incidence and development of a foliar fungal plant disease. Ecology 92: 1551-1558.

Kable, P. F., and Ballantyne, B. J. 1963. Observation on the cucurbit powdery mildew in the Ithaca district. Plant Dis. Rep. 47:482.

Keinath, A. P. 1996. Soil amendment with cabbage residue and crop rotation to reduce gummy stem blight and increase growth and yield of watermelon. Plant Dis. 80:564-570.

Keinath, A. P. 2001. Effect of fungicide applications scheduled to control gummy stem blight on yield and quality of watermelon fruit. Plant Dis. 85:53-58.

Keinath, A. P. 2002. Survival of Didymella bryoniae in buried watermelon vines in South Carolina. Plant Dis. 86:32-38.
Keinath, A. P. 2008. Survival of Didymella bryoniae in infested muskmelon crowns in South Carolina. Plant Dis. 92:1223-1228.

Keinath, A. P. 2014. Differential susceptibility of nine cucurbit species to the foliar blight and crown canker phases of gummy stem blight. Plant Dis. 98:247-254

Keinath, A. P. 2015a. Identification of races of Colletotrichum orbiculare on muskmelon in South Carolina. Plant Health Prog. 16:88-89.

Keinath, A. P. 2015b. Baseline sensitivity of Didymella bryoniae to cyprodinil and fludioxonil and field efficacy of these fungicides against isolates resistant to pyraclostrobin and boscalid. Plant Dis. 99:815-822.

Keinath, A. P. 2015c. Efficacy of fungicides against powdery mildew on watermelon caused by Podosphaera xanthii. Crop Prot. 75:70-76.

Keinath, A. P. 2016. Utility of a cucumber plant bioassay to assess fungicide efficacy against Pseudoperonospora cubensis. Plant Dis. 100:490-499.

Keinath, A. P. 2017a. Anthracnose. Pages 54-56 in: Compendium of Cucurbit Diseases and Pests, 2nd Ed. A. P. Keinath, W. M. Wintermantel, and T. A. Zitter, eds. American Phytopathological Society, St. Paul, MN.

Keinath, A. P. 2017b. Gummy stem blight. Pages 59-60 in: Compendium of Cucurbit Diseases and Pests, 2nd Ed. A. P. Keinath, W. M. Wintermantel, and T. A. Zitter, eds. American Phytopathological Society, St. Paul, MN

Keinath, A. P. 2018. Minimizing yield and quality losses in watermelon with multi-site and strobilurin fungicides effective against foliar and fruit anthracnose. Crop Prot. 106:72-78.

Keinath, A. P., and Hassel, R. L. 1999. Evaluation of diploid and triploid watermelon cultivars for field resistance to anthracnose and gummy stem blight. Biol. Cult. Tests 14:188.

Keinath, A. P., and Hassel, R. L. 2000. Evaluation of diploid and triploid watermelon cultivars for susceptibility to powdery mildew and gummy stem blight. Biol. Cult. Tests 15:193.

Keinath, A. P., Holmes, G. J., Everts, K. L., Egel, D. S., and Langston, D. B., Jr. 2007. Evaluation of combinations of chlorothalonil with azoxystrobin, harpin, and disease forecasting for control of downy mildew and gummy stem blight on melon. Crop Prot. 26:83-88.

Kemble, J. M., Meadows, I. M., Jennings, K. M., and Walgenbach, J. F., eds. 2018 Vegetable Crop Handbook for the Southeastern United States. Southeastern Vegetable Extension Workers Group. https://www.growingproduce.com/ southeasternvegetablecrophandbook/

Kirchner, J. W. 2006. Getting the right answers for the right reasons: Linking measurements, analyses, and models to advance the science of hydrology. Water Resour. Res. 42:W03S04.

Kousik, C. S., Brusca, J., and Turechek, W. W. 2016. Diseases and disease management strategies take top research priority in the Watermelon Research and Development Group members survey (2014 to 2015). Plant Health Prog. 17:53-58.

Kousik, C. S., Mandal, M., and Hassel, R. 2018. Powdery mildew resistant rootstocks that impart tolerance to grafted susceptible watermelon scion seedlings. Plant Dis. 102:1290-1298.

Li, H.-X., and Brewer, M. T. 2016. Spatial genetic structure and population dynamics of gummy stem blight fungi within and among watermelon fields in the southeastern United States. Phytopathology 106:900-908.

Lombard, L., Houbraken, J., Decock, C., Samson, R. A., Meijer, M., Réblová, M., Groenewald, J. Z., and Crous, P. W. 2016. Generic hyper-diversity in Stachybotriaceae. Persoonia 36:156-246.

McGrath, M. T. 2001. Fungicide resistance in cucurbit powdery mildew: Experiences and challenges. Plant Dis. 85:236-245.

McGrath, M. T. 2017. Powdery mildew. Pages 62-64 in: Compendium of Cucurbit Diseases and Pests, 2nd Ed. A. P. Keinath, W. M. Wintermantel, and T. A. Zitter, eds. American Phytopathological Society, St. Paul, MN.

Motrenko, A., Strijov, V., and Weber, G.-H. 2014. Sample size determination for logistic regression. J. Comput. Appl. Math. 255:743-752.

Neufeld, K. N., Keinath, A. P., Gugino, B. K., McGrath, M. T., Sikora, E. J., Miller, S. A., Ivey, M. L., Langston, D. B., Dutta, B., Keever, T., Sims, A., and Ojambo, P. S. 2018. Predicting the risk of cucurbit downy mildew in the eastern United States using an integrated aerobiological model. Int. J. Biometeorol. 62:655-668.

Oerke, E.-C., Meier, A., Dehne, H.-W., Sulyok, M., Krska, R., and Steiner, U. 2010. Spatial variability of Fusarium head blight pathogens and associated mycotoxins in wheat crops. Plant Pathol. 59:671-682.

Ojiambo, P. S., Gent, D. H., Quesada-Ocampo, L. M., Hausbeck, M. K., and Holmes, G. J. 2015. Epidemiology and population biology of Pseudoperonospora cubensis: A model system for management of downy mildews. Annu. Rev. Phytopathol. 53:223-246.

Ojiambo, P. S., Paul, P. A., and Holmes, G. J. 2010. A quantitative review of fungicide efficacy for managing downy mildew in cucurbits. Phytopathology 100:1066-1076

Peterson, P. D., and Campbell, C. L. 2002. Prevalence and ecological association of foliar pathogens of cucumber in North Carolina. Plant Dis. 86:1094-1100.

Pethybridge, S. J., and Hay, F. S. 2001. Influence of Phoma ligulicola on yield, and site factors on disease development, in Tasmanian pyrethrum crops. Australas. Plant Pathol. 30:17-20.

Prussin, A. J., II, Marr, L. C., Schmale, D. G., III, Stoll, R., and Ross, S. D. 2015 Experimental validation of a long-distance transport model for plant pathogens: Application to Fusarium graminearum. Agric. For. Meteorol. 203:118-130. 
Raichle, B. W., and Carson, W. R. 2009. Wind resource assessment of the Southern Appalachian Ridges in the Southeastern United States. Renew. Sustain. Energy Rev. 13:1104-1110.

Rao, P. S. R. S. 2000. Sampling methodologies with applications. Chapman \& Hall/CRC, Boca Raton, FL.

Rennberger, G., Gerard, P., and Keinath, A. P. 2018. Occurrence of foliar pathogens of watermelon on commercial farms in South Carolina estimated with stratified cluster sampling. Plant Dis. 102:2285-2295.

Rennberger, G., and Keinath, A. P. 2018. Susceptibility of fourteen new cucurbit species to gummy stem blight caused by Stagonosporopsis citrulli Under Field Conditions. Plant Dis. 102:1365-1375.

Rossi, V., Caffi, T., and Legler, S. E. 2010. Dynamics of ascospore maturation and discharge in Erysiphe necator, the causal agent of grape powdery mildew. Phytopathology 100:1321-1329.

Shtienberg, D., and Fry, W. E. 1990. Influence of host resistance and crop rotation on initial appearance of potato early blight. Plant Dis. 74:849-852.

Sitterly, W. R. 1969. Effect of crop rotation on cucumber gummy stem blight. Plant Dis. Rep. 53:417-419.

Stewart, J. E., Turner, A. N., and Brewer, M. T. 2015. Evolutionary history and variation in host range of three Stagonosporopsis species causing gummy stem blight of cucurbits. Fungal Biol. 119:370-382.
Thomas, A., Carbone, I., Cohen, Y., and Ojiambo, P. S. 2017. Occurrence and distribution of mating types of Pseudoperonospora cubensis in the United States. Phytopathology 107:313-321.

Uloth, M. B., You, M. P., and Barbetti, M. J. 2018. Plant age and ambien temperature: Significant drivers for powdery mildew (Erysiphe cruciferarum) epidemics on oilseed rape (Brassica napus). Plant Pathol. 67:445-456.

USDA, NASS. 2014. Vegetables 2013 Summary. Available online at http://usda mannlib.cornell.edu/usda/nass/VegeSumm/2010s/2014/VegeSumm-03-272014.pdf

USDA, NASS. 2018. Vegetables 2017 Summary. Available online at http://usda mannlib.cornell.edu/usda/current/VegeSumm/VegeSumm-02-13-2018.pdf

Van Steekelenburg, N. A. M. 1983. Epidemiological aspects of Didymella bryoniae, the cause of stem and fruit rot of cucumber. Neth. J. Plant Pathol. 89:75-86.

Viljanen-Rollinson, S. L. H., Parr, E. L., and Marroni, M. V. 2007. Monitoring long-distance spore dispersal by wind - a review. N.Z. Plant Prot. 60:291-296.

Wasilwa, L. A., Correll, J. C., Morelock, T. E., and McNew, R. E. 1993. Reexamination of races of the cucurbit anthracnose pathogen Colletotrichum orbiculare. Phytopathology 83:1190-1198.

Zhang, Y.-J., Pu, Z.-J., Qin, Z.-W., Zhou, X.-Y., Liu, D., Dai, L.-T., and Wang, W.-B. 2012. A study on the overwintering of cucumber downy mildew oospores in China. J. Phytopathol. 160:469-474. 